
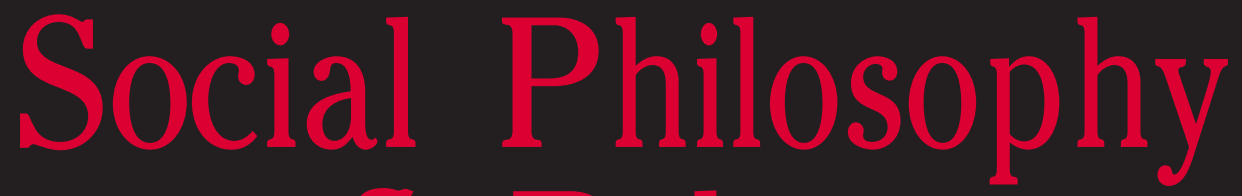

\title{
Equality and Public Policy
}

\section{CONTENTS}

GERALD GAUS

SCOTT WINSHIP

ELIZABETH ANDERSON

STEVEN HORWITZ

PAUL WEITHMAN

DEBRA THOMPSON

SARAH E. SKWIRE

GOVIND PERSAD

ANTONY DAVIES,

JAMES R. HARRIGAN, and

MEGAN TEAGUE

KRISTIN VOIGT and

GRY WESTER

TOM W. BELL

DANIEL L. BENNETT and RICHARD K. VEDDER
The Egalitarian Species

1

Has Rising Income Inequality Worsened Inequality of Opportunity in the United States?

Equality and Freedom in the Workplace: Recovering Republican Insights

48

Inequality, Mobility, and Being Poor in America

70

Relational Equality, Inherent Stability, and the

Reach of Contractualism

92

What Lies Beneath: Equality and the Making of

Racial Classifications

"Without Respect of Persons": Gender Equality, Theology, and the Law in the Writing of Margaret Fell

Equality via Mobility: Why Socioeconomic Mobility Matters for Relational Equality, Distributive Equality, and Equality of Opportunity

Equality, Liberty, and Prosperity

Relational Equality and Health

What Can Corporations Teach Governments about Democratic Equality?

Public Policy, Higher Education, and Income Inequality in the United States: Have We Reached Diminishing Returns? 


\section{Social Philosophy ๘ Policy}

ISSN 0265-0525

Editor: David Schmidtz, University of Arizona

Founder and Editor Emeritus: Ellen Frankel Paul

Executive Editors: Fred D. Miller, Jr., and Jeffrey Paul

Associate Editor: Carmen Pavel, University of Arizona

Administrative Editor: Tamara Sharp

Managing Editor: Pamela Phillips

Guest Editors: Mark LeBar and Antony Davies

Baruch Brody

Rice University

Jules L. Coleman

New York University

Tyler Cowen

George Mason University

Richard A. Epstein

New York University School of Law

James S. Fishkin

Stanford University

Gilbert Harman

Princeton University

\section{Editorial Board}

Daniel Jacobson

University of Michigan

Chandran Kukathas

London School of Economics and Political Science

Loren E. Lomasky

University of Virginia

Eric Mack

Tulane University

Harvey C. Mansfield

Harvard University

Michael C. Munger

Duke University
Jan Narveson

University of Waterloo

Nicholas Rescher

University of Pittsburgh

Geoffrey Sayre-McCord

University of North Carolina-Chapel Hill

Hillel Steiner

University of Manchester

University of Arizona

Michael Zuckert

University of Notre Dame

\section{Copyright (c) 2015 Social Philosophy and Policy Foundation}

All rights reserved. No part of this publication may be reproduced, in any form or by any means, electronic, photocopying or otherwise, without permission in writing from Social Philosophy \& Policy. Photocopying information for users in the USA: The Item-Free Code for this publication (0265-0525/12 \$15.00) indicates that copying for internal or personal use beyond that permitted by Sec. 107 or 108 of the U.S. Copyright Law is authorized for users duly registered with the Copyright Clearance Center (CCC) Transaction Reporting Service, provided that the appropriate remittance is paid directly to: CCC, 222 Rosewood Drive, Danvers, MA 01923. Specific written permission must be obtained from Social Philosophy \& Policy for all other copying. 